\title{
Characteristics of misreporters of dietary intake and physical activity
}

\author{
Lone Banke Rasmussen*, Jeppe Matthiessen, Anja Biltoft-Jensen and Inge Tetens \\ Department of Nutrition, Danish Institute for Food and Veterinary Research, Mørkhøj Bygade 19, \\ DK-2860 Søborg, Denmark
}

Submitted 16 March 2006: Accepted 30 August 2006

\begin{abstract}
Objective: To characterise misreporters of energy intake (EI) and energy expenditure (EE).

Design: Cross-sectional study, using a validated position and motion instrument, ActiReg ${ }^{\circledR}$, as the reference method to study misreporters of EI and of EE. EI was measured using a dietary record and EE using a physical activity questionnaire (PAQ). Misreporters were defined as subjects outside the 95\% confidence limits of agreement between EI or EE reported/EE measured.

Setting: Free-living Danish volunteers.

Subjects: One hundred and thirty-eight volunteers aged between 20 and 59 years.

Results: Body mass index, smoking, 'try to eat healthily' and worries about weight were related to degree of under-reported EI. The percentage energy from added sugar was lowest $(P<0.001)$ and the percentage energy from protein $(P<0.001)$ highest in under-reporters compared with acceptable reporters. Subjects who reported being very physically active at work or in leisure time reported a higher EE than measured EE compared with less physically active subjects $(P<0.05)$. Likewise, subjects who regard themselves as fit or very fit reported a higher EE than subjects who regard themselves as moderately fit $(P<0.05)$. Possible over-reporters reported less time as very light activity $(P=0.007)$, more time as moderate activity $(P=0.01)$ and more time as vigorous activity $(P=0.02)$ than acceptable reporters.

Conclusions: Under-reporting of EI should always be taken into consideration; however, only a few characteristics of under-reporters are consistent among studies. Misreporting of EI was more prevalent than misreporting of EE. The level of physical activity more than the time spent involved in various activities was misreported.
\end{abstract}

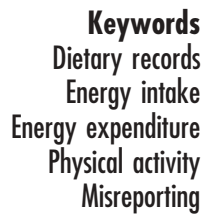

Keywords Dietary records gy intake hysical activity Misreporting
Under-reporting of energy intake (EI) is a common problem in dietary studies. Characteristics of underreporters have been investigated in a number of studies using various methods, but the results have not been consistent. The most common finding is a relationship between increased under-reporting and increased body mass index (BMI). This relationship is found in most ${ }^{1-4}$ but not all ${ }^{5,6}$ studies. However, a relationship with body fat is not always found; in a study in women, a relationship between percentage body fat and under-reporting was not found, although a relationship with BMI was found ${ }^{2}$, whereas in another study the opposite relationships were found ${ }^{6}$.

Under-reporting has been found to increase with increasing age $\mathrm{e}^{1,3,7}$ and to be more frequent in women than in men ${ }^{5-7}$. However, in Denmark, this trend has not been identified recently ${ }^{8}$. Other characteristics of underreporters are less frequently identified. Smokers have been found to under-report EI less frequently than non-smokers ${ }^{1,7,9}$, although this finding has not been consistent $^{10}$. Furthermore, educational level has been associated with under-reporting, but both a high and a low educational level has been related to under-reporting, and many studies did not find a relationship at all ${ }^{10}$.

Under-reporting seems to concern specific food items. For instance, many studies have found that the percentage of energy from fat was lower in under-reporters than in acceptable reporters, whereas the percentage of energy from protein and carbohydrate was highest in underreporters ${ }^{10}$. It has been reported that sugar-rich and/or fatrich foods were less reported by under-reporters, whereas the intake of vegetables, fruit and fish was similar in underreporters and acceptable reporters ${ }^{11,12}$.

Energy expenditure (EE) has only been measured in a few studies, and under-reporting of EI has often been determined by calculating estimated EI divided by the basal metabolic rate $(\mathrm{EI} / \mathrm{BMR})^{10}$. Values of EI/BMR below the $95 \%$ confidence limit (CL) of agreement between these 
two measures, the Goldberg cut-off, signify the presence of under-reporting ${ }^{13}$. However, this cut-off value is based on a sedentary physical activity level. Cut-off values depending on individual physical activity level provide a better definition of under-reporters ${ }^{14}$. EE is sometimes calculated from physical activity questionnaires. This makes the validity, and the characteristics of misreporters, of EE interesting.

The problem of misreporting EE is less studied than misreporting of EI. Most studies indicate over-reporting of $\mathrm{EE}^{15}$. However, in a study with a high degree of overreporting, it was not possible to identify any common characteristics of the individuals who over-report ${ }^{16}$. Misreporting of EE could be due to misreporting of frequency, intensity or duration of activity; however, this has not been much studied. One study indicates that reports of vigorous physical activity were relatively accurate $^{17}$, and in another study it was found that moderate intensity activities were underestimated ${ }^{18}$.

The aim of the present study was to characterise misreporters of EI as well as misreporters of EE among Danish adults using a validated position and motion instrument, ActiReg ${ }^{\circledR}$, as the reference method measuring EE.

\section{Materials and methods}

\section{Design}

Volunteers filled in a physical activity questionnaire (PAQ) and kept dietary records for seven consecutive days. ActiReg ${ }^{\circledR}$, an electronic device which records body position and movement, was carried on the same days as the dietary records and the PAQ were filled in. All subjects were interviewed about health issues, etc. After completion of the interview, the subjects were instructed how to fill in the dietary record and the PAQ and how to use the ActiReg ${ }^{\circledR}$ equipment. Written instructions were also delivered.

For a subject to be included in the study, at least 4 days had to be available for dietary record, PAQ and ActiReg ${ }^{\circledR}$ measurement. Three subjects had four applicable days, seven had 5 days, 24 had 6 days and the remaining 104 had all 7 days.

\section{Subjects}

Healthy Danish volunteers aged 20-59 years were recruited through advertisements in local firms, a local newspaper and a website. An equal representation of men and women as well as of the various age groups was aimed at. Pregnant women, athletes and subjects on a slimming diet were excluded. One hundred and fortythree subjects completed the study. Data from two subjects were excluded due to problems with the ActiReg ${ }^{\circledR}$, two subjects had mounted the ActiReg ${ }^{\circledR}$ sensors erroneously and one subject did not return the diet records and the PAQs, which left 138 subjects with useful data. Of these, seven subjects agreed to repeat the protocol because of technical problems with the ActiReg ${ }^{\circledR}$.

\section{Dietary intake and personal interview}

The dietary recording method was a combination of a personal interview and self- administered dietary records. The interview took $\sim 20 \mathrm{~min}$ and included information about social background, selected health data, hours usually spent sleeping and more detailed information about attitudes to dietary habits and physical activity as well as information on use of some common foods. Subjects were instructed to record their dietary intake for seven consecutive days in supplied booklets with precoded fixed answer possibilities supplemented with a possibility for open answers. The booklets were divided into five meals; breakfast, lunch, hot dinner, cold dinner and snacks. Food portion sizes were estimated from household measures and a series of photographs. Each series of photographs consists of four or, in most cases, six photographs of different portion sizes. The booklet for dietary record was used in a nationwide dietary survey ${ }^{19}$. Subjects were instructed to eat as usual during the course of the study. Intakes of nutrients and foods were calculated using the General Intake Estimation System (GIES) (Version 0.995a, released 26 June 2005; Danish Institute for Food and Veterinary Research) based on the Danish food database ${ }^{20}$.

\section{Physical activity questionnaire and reported energy expenditure ( $\left.E_{\text {rep }}\right)$}

A PAQ was filled in daily for the same 7 days as the dietary record. The questionnaire was a modified version of the long self-administered International Physical Activity Questionnaire (IPAQ). The PAQ collects information on time and physical activity level (very light $(1<$ MET $<2.3)$, light $(2.3 \leq \mathrm{MET}<3)$, moderate $(3 \leq \mathrm{MET}<6)$ and vigorous (MET >6)) within the domains of occupational activity transport, household and yard/garden activities, leisure-time physical activity and sedentary activity during leisure time, and covered all hours awake. If the sum of all activity domains was $<16 \mathrm{~h}$ (including hours spent sleeping), the day was omitted. Six days were omitted for that reason. The PAQ was used in a Danish nationwide dietary survey.

BMR was calculated for each individual using the Schofield equation ${ }^{21}$ based on self-reported weight. The daily physical activity level (PAL) was calculated using the factorial method by multiplying time spent in each activity category by the respective metabolic equivalent value (MET), and then dividing the METhours by 24. MET values were based on international tables $^{22,23}$. Daily EE was calculated as PAL multiplied by BMR for each individual, and the mean for the 7 days was used as reported $\mathrm{EE}\left(\mathrm{EE}_{\mathrm{rep}}\right)$. 
Energy expenditure measured by ActiReg ${ }^{\circledR}\left(E_{\text {mea }}\right)$ ActiReg ${ }^{\circledR}$ (PreMed AS) is an electronic device which records body position and movement. It has two body position sensors and two motion sensors connected by cables to a battery-operated storage unit. During registration, one bracket is attached by medical tape to the chest (on the sternum) and the other on the front of the right thigh approximately midway between the knee and the hip. The storage unit is fixed to an elastic belt worn around the waist. The principle of the ActiReg ${ }^{\circledR}$ and validation of the method have been published ${ }^{24}$. The subjects in the present study carried the ActiReg ${ }^{\circledR}$ for seven consecutive days except when they slept at night, when taking a shower and if swimming. If the ActiReg ${ }^{\circledR}$ was not carried for a period of $15 \mathrm{~min}$ or more, the subject recorded the type of activity during that time on a diagram and EE was estimated for that time and activity, and was included when the total $\mathrm{EE}$ for that particular day was calculated. If the ActiReg ${ }^{\circledR}$ was not carried for $3 \mathrm{~h}$ or more during a day, the day was omitted. Twenty-one days were omitted for that reason. Furthermore, a total of 20 days were omitted due to incorrect placement of the sensors.

Collected data were transferred to a computer and processed by a specially designed program called ActiCalc. PAL was calculated from the measured activity levels and body positions as described by Hustvedt et al. $^{24}$. BMR was calculated from the equation published by Garby et $a l^{25}$ based on body composition data from measurements of electrical impedance ${ }^{26}$. EE was calculated for each individual as PAL multiplied by BMR. The mean of the applicable days was used as measured $\mathrm{EE}\left(\mathrm{EE}_{\mathrm{mea}}\right)$.

\section{General information}

The ActiReg ${ }^{\circledR}$ was carried on the same days as the dietary records and the PAQ were filled in.

\section{Anthropometric measurements}

Height and body weight were measured in all subjects without shoes. Height was measured to the nearest $\mathrm{cm}$ with a Seca 222. Subjects were weighed with indoor clothing to the nearest $0.1 \mathrm{~kg}$ on an electronic scale (Rowenta Silver Art). Body weight was also measured after the recording period on the same scale. Lastly, body composition was measured using a bioelectrical impedance analyser (Maltron BF-906; Maltron International Ltd) after at least $5 \mathrm{~min}$ rest in the supine position.

\section{Calculation of misreporters}

Misreporters of EI were defined from their ratio of $\mathrm{EI}_{\text {rep }}$ to $\mathrm{EE}_{\text {mea }}$. The 95\% CLs of agreement between $\mathrm{EI}_{\text {rep }} / \mathrm{EE}_{\text {mea }}$ were calculated as

$$
95 \% \mathrm{CL}= \pm 2 \sqrt{ }\left[\left(C V_{\mathrm{El}}^{2} / d\right)+\left(C V_{\mathrm{EE}}^{2} / d\right)\right]
$$

where $C V_{\mathrm{EI}}$ was the coefficient of variation for the reported $\mathrm{EI}$ (23.6), $C V_{\mathrm{EE}}$ the coefficient of variation for the
$\mathrm{EE}_{\text {mea }}(21.1)$ and $d$ the number of days (7). The 95\% CL was calculated to $\pm 24 \%$. Acceptable reporters were defined as having a ratio $\mathrm{EI}_{\mathrm{rep}} / \mathrm{EE}_{\text {mea }}$ in the range $76-$ $124 \%$, under-reporters as $\mathrm{EI}_{\text {rep }} / \mathrm{EE}_{\text {mea }}<76 \%$ and overreporters as $\mathrm{EI}_{\text {rep }} / \mathrm{EE}_{\text {mea }}>124 \%$.

Likewise, misreporters of $\mathrm{EE}$ were defined from their ratio $\mathrm{EE}_{\text {rep }} / \mathrm{EE}_{\text {mea }}$. The $95 \%$ CLs of agreement between $\mathrm{EE}_{\text {rep }} / \mathrm{EE}_{\text {mea }}$ were calculated using the formula described above, where $C V_{\text {EErep }}$, the coefficient of variation for the $\mathrm{EE}_{\text {rep }}$ (21.0), replaced $C V_{\mathrm{EI}} \cdot C V_{\text {EEmea }}$, the coefficient of variation for the $\mathrm{EE}_{\text {mea }}$, was 21.1, and the number of days, $d=7$. The $95 \%$ CL was calculated to $\pm 22 \%$. Acceptable reporters of $\mathrm{EE}$ were defined as having a ratio of $\mathrm{EE}_{\text {rep }} / \mathrm{EE}_{\text {mea }}$ in the range $78-122 \%$, under-reporters of $\mathrm{EE}$ as $\mathrm{EE}_{\text {rep }} / \mathrm{EE}_{\text {mea }}<78 \%$ and over-reporters of $\mathrm{EE}$ as $\mathrm{EE}_{\text {rep }} / \mathrm{EE}_{\text {mea }}>122 \%$.

As so few misreported $\mathrm{EE}$ according to the above definition, possible misreporters were used for some analyses. Possible misreports of EE was defined to be $<90 \%$ of the $\mathrm{EE}_{\text {mea }}$ or $>110 \%$ of the $\mathrm{EE}_{\text {mea }}$.

\section{Statistics}

For statistical analysis, SPSS version 12.0 software (SPSS Inc.) was used. Univariate analyses of differences between mean values were calculated with analysis of variance with Tukey's post hoc test. For calculation of the correlation between two measures, Spearman's rho were calculated. Differences in dietary intake between under-reporters and acceptable reporters were evaluated using the Mann-Whitney test. Likewise, differences in reported time involved in various activity domains and of physical activity levels between misreporters and acceptable reporters were evaluated using the Mann-Whitney test. To study the determinants of under-reporting, multiple linear regression analyses were performed with relative under-reporting as the dependent variable and the determinants studied as independent variables.

\section{Results}

Characteristics of the subjects, reported EI $\left(\mathrm{EI}_{\mathrm{rep}}\right)$, reported $\mathrm{EE}\left(\mathrm{EE}_{\mathrm{rep}}\right)$ as well as measured $\mathrm{EE}\left(\mathrm{EE}_{\text {mea }}\right)$ are given in Table 1.

Table 2 shows the number of under-reporters, acceptable reporters and over-reporters of EI and EE, respectively. Thirty-six subjects $(26 \%, 21$ men and 15 women) under-reported EI, whereas only two subjects (1.4\%, one man and one woman) over-reported EI. Likewise, five subjects (3.6\%, three men and two women) under-reported EE and two subjects (1.4\%, both men) over-reported EE. Furthermore, the number who under-reported both EI and EE as well as other combinations of reported EI and EE are shown. Only three of the 36 under-reporters of EI under-reported EE and one over-reported EE. 
Table 1 Characteristics of the study population

\begin{tabular}{|c|c|c|}
\hline & $\begin{array}{c}\text { Men } \\
(n=69)\end{array}$ & $\begin{array}{l}\text { Women } \\
(n=69)\end{array}$ \\
\hline \multicolumn{3}{|l|}{ Age (years) $(n(\%))$} \\
\hline $20-29$ & $16(23)$ & $17(25)$ \\
\hline $30-39$ & $19(28)$ & $17(25)$ \\
\hline $40-49$ & $18(26)$ & $16(23)$ \\
\hline $50-59$ & $16(23)$ & $19(28)$ \\
\hline \multicolumn{3}{|l|}{$\mathrm{BMI}\left(\mathrm{kg} \mathrm{m}^{-2}\right)(n(\%))$} \\
\hline$<18.5$ & $1(1)$ & $0(0)$ \\
\hline $18.5-24.9$ & 27 (39) & 38 (55) \\
\hline $25-29.9$ & $33(48)$ & $26(38)$ \\
\hline$>30$ & $8(12)$ & $5(7)$ \\
\hline Percentage body fat (mean \pm SD) & $23.5 \pm 6.4$ & $31.9 \pm 6.3$ \\
\hline \multicolumn{3}{|l|}{ Smoking habits $(n(\%))$} \\
\hline Non-smokers & $54(78)$ & $60(87)$ \\
\hline Smokers & $12(17)$ & $6(9)$ \\
\hline Occasional smokers & $3(4)$ & $3(4)$ \\
\hline \multicolumn{3}{|l|}{ Education $(n(\%))$} \\
\hline Student $(n=19)$ & $8(12)$ & $11(16)$ \\
\hline None or $<12$ years $(n=44)$ & $27(39)$ & $17(25)$ \\
\hline $13-14$ years $(n=17)$ & $5(7)$ & $12(17)$ \\
\hline $15-16$ years $(n=27)$ & $12(17)$ & $15(22)$ \\
\hline$\geq 17$ years $(n=31)$ & $17(25)$ & $14(20)$ \\
\hline $\begin{array}{l}\text { Body weight before recording }(\mathrm{kg}) \\
\text { (mean } \pm \text { SD) }\end{array}$ & $84.4 \pm 13.4$ & $69.3 \pm 9.8$ \\
\hline $\begin{array}{l}\text { Body weight after recording }(\mathrm{kg}) \\
\quad(\text { mean } \pm \mathrm{SD})\end{array}$ & $84.1 \pm 13.2$ & $69.1 \pm 9.7$ \\
\hline $\mathrm{El}_{\text {rep }}\left(\mathrm{MJ} \mathrm{day}^{-1}\right)($ mean $\pm \mathrm{SD})$ & $11.8 \pm 2.3$ & $9.0 \pm 1.7$ \\
\hline $\mathrm{EE}_{\mathrm{rep}}\left(\mathrm{MJ}\right.$ day $\left.^{-1}\right)($ mean $\pm \mathrm{SD})$ & $13.2 \pm 2.4$ & $9.9 \pm 1.0$ \\
\hline $\mathrm{EE}_{\text {mea }}\left(\mathrm{MJ} \mathrm{day}^{-1}\right)($ mean $\pm \mathrm{SD})$ & $13.9 \pm 2.2$ & $10.2 \pm 1.1$ \\
\hline
\end{tabular}

$\mathrm{EI}_{\text {rep }}$ as a percentage of $\mathrm{EE}_{\text {mea }}$ (relative under-reporting) is given in Table 3 for various subject characteristics. Sex, age and education were not related to degree of underreporting EI, but BMI, smoking, 'try to eat healthily' and worries about body weight were.

In a multiple linear regression model with $\mathrm{EI}_{\text {rep }}$ as a percentage of $\mathrm{EE}_{\text {mea }}$ as the dependent variable and the variables given in Table 3 as independent variables, BMI, 'try to eat healthily' and worries about weight remained statistically significantly associated with the degree of under-reporting. This was not changed if the percentage body fat was included in the model (results not shown).

The percentage body fat was found to be statistically significantly correlated with the degree of misreporting in

Table 2 Number of misreporters of energy intake and energy expenditure

\begin{tabular}{lcrcr}
\hline & \multicolumn{4}{c}{ EE $_{\text {rep }}$} \\
\cline { 2 - 5 } El $_{\text {rep }}$ & UR & AR & OR & Total \\
\hline UR & 3 & 32 & 1 & 36 \\
AR & 2 & 97 & 1 & 100 \\
OR & 0 & 2 & 0 & 2 \\
Total & 5 & 131 & 2 & 138
\end{tabular}

$\mathrm{EI}_{\text {rep }}$ - reported energy intake; $\mathrm{EE}_{\text {rep }}$ - reported energy expenditure; UR under-reporters; AR - acceptable reporters; OR - over-reporters. men $(r=-0.35, \quad P=0.003)$ but not in women ( $r=-0.10, P=0.4$ ). Furthermore, subjects who claimed to have eaten as usual misreported to the same degree as subjects who claimed to have eaten a little differently or very differently from usual (results not shown).

Table 4 shows dietary intake in under-reporters of EI compared with acceptable reporters. Over-reporters of EI are not included due to the low number. The percentage energy from added sugar was significantly lower and the percentage energy from protein significantly higher in under-reporters than in acceptable reporters.

Table 3 Reported energy intake as a percentage of measured energy expenditure and various subject characteristics

\begin{tabular}{|c|c|}
\hline & $\begin{array}{c}\mathrm{EI}_{\text {rep }} \text { as a percentage of } \\
\left.\mathrm{EE}_{\text {mea }} \text { (mean } \pm \mathrm{SD}\right)\end{array}$ \\
\hline \multicolumn{2}{|l|}{ Gender } \\
\hline Men $(n=69)$ & $87.0 \pm 19.3$ \\
\hline Women $(n=69)$ & $88.8 \pm 14.5$ \\
\hline \multicolumn{2}{|l|}{ Age (years) } \\
\hline $20-29(n=33)$ & $88.7 \pm 18.2$ \\
\hline $30-39(n=36)$ & $87.9 \pm 16.5$ \\
\hline $40-49(n=34)$ & $87.9 \pm 15.2$ \\
\hline $50-59(n=35)$ & $87.1 \pm 18.6$ \\
\hline \multicolumn{2}{|l|}{ Smoking } \\
\hline Smokers $(n=18)$ & $97.0 \pm 20.8^{a}$ \\
\hline Occasional smokers $(n=6)$ & $81.4 \pm 16.7$ \\
\hline Non-smokers $(n=114)$ & $86.8 \pm 17.0^{\star b}$ \\
\hline \multicolumn{2}{|l|}{ Education } \\
\hline Student $(n=19)$ & $87.2 \pm 14.7$ \\
\hline None or $<12$ years $(n=44)$ & $86.7 \pm 20.5$ \\
\hline $13-14$ years $(n=17)$ & $90.0 \pm 13.5$ \\
\hline $15-16$ years $(n=27)$ & $87.8 \pm 16.5$ \\
\hline$\geq 17$ years $(n=31)$ & $88.9 \pm 15.8$ \\
\hline \multicolumn{2}{|l|}{ BMl $\left(\mathrm{kg} \mathrm{m}^{-2}\right)$} \\
\hline$<18.5(n=1)$ & $123.5 \pm 0$ \\
\hline $18.5-24.9(n=65)$ & $91.0 \pm 16.0^{\mathrm{a}}$ \\
\hline $25-29.9(n=59)$ & $86.5 \pm 15.3$ \\
\hline$\geq 30(n=13)$ & $75.6 \pm 21.7^{\star b}$ \\
\hline \multicolumn{2}{|l|}{ Try to eat healthily } \\
\hline Yes, very often $(n=31)$ & $81.3 \pm 15.3^{a}$ \\
\hline Yes, often $(n=77)$ & $88.0 \pm 16.7$ \\
\hline Occasionally $(n=26)$ & $92.6 \pm 17.1$ \\
\hline No, never $(n=4)$ & $105.2 \pm 19.8^{\star b}$ \\
\hline \multicolumn{2}{|l|}{ Believe their diet is healthy } \\
\hline Yes, very $(n=25)$ & $83.6 \pm 15.4$ \\
\hline Yes, to some extent $(n=75)$ & $89.1 \pm 17.1$ \\
\hline No $(n=37)$ & $88.5 \pm 18.0$ \\
\hline \multicolumn{2}{|l|}{ Physical activity in leisure time } \\
\hline None $(n=11)$ & $97.2 \pm 15.4$ \\
\hline Light $2-4$ h week $^{-1}(n=52)$ & $86.2 \pm 16.1$ \\
\hline Light $>4$ h week $^{-1}(n=61)$ & $86.8 \pm 16.9$ \\
\hline More vigorous $>4 \mathrm{~h}^{-1}$ week $^{-1}(n=14)$ & $91.5 \pm 20.6$ \\
\hline \multicolumn{2}{|l|}{ Believe they are in good health } \\
\hline Excellent $(n=35)$ & $87.8 \pm 14.3$ \\
\hline Very good $(n=55)$ & $87.8 \pm 17.9$ \\
\hline Good $(n=41)$ & $88.0 \pm 15.9$ \\
\hline Not so good $(n=7)$ & $88.1 \pm 30.1$ \\
\hline \multicolumn{2}{|l|}{ Eat healthily to avoid being overweight $\dagger$} \\
\hline Yes $(n=56)$ & $82.9 \pm 16.4$ \\
\hline Did not mention it $(n=78)$ & $90.6 \pm 16.3^{\star}$ \\
\hline
\end{tabular}

$\mathrm{EI}_{\text {rep }}$ - reported energy intake; $\mathrm{EE}_{\text {mea }}$ - measured energy expenditure; $\mathrm{SD}$ - standard deviation; BMI - body mass index.

†The subjects who claimed they try to eat healthily were asked why; 56 subjects said it was to avoid being overweight or to lose weight. ${ }^{*} P<0.05 ;{ }^{* *} P<0.005$ (one-way analysis of variance).

${ }^{\mathrm{ab}}$ Different letters indicate significant difference, $P<0.05$, by Tukey post hoc test. 
Table 4 Dietary composition in under-reporters and acceptable reporters of energy intake

\begin{tabular}{lcc}
\hline & $\begin{array}{c}\text { Under-reporters } \\
(n=36)(\text { mean } \pm \mathrm{SD})\end{array}$ & $\begin{array}{c}\text { Acceptable reporters } \\
(n=100) \text { (mean } \pm \text { SD) }\end{array}$ \\
\hline Fat $(\mathrm{E} \%)$ & $30.7 \pm 3.7$ & $31.4 \pm 5.0$ \\
Carbohydrate $(\mathrm{E} \%)$ & $49.1 \pm 5.2$ & $50.1 \pm 5.5$ \\
Alcohol $(\mathrm{E} \%)$ & $5.5 \pm 5.1$ & $5.2 \pm 4.9$ \\
Protein $(\mathrm{E} \%)$ & $15.5 \pm 1.8$ & $14.1 \pm 1.9^{\star}$ \\
Added sugar $(\mathrm{E} \%)$ & $7.1 \pm 3.6$ & $10.6 \pm 5.8^{\star}$ \\
Dietary fibre $\left(\mathrm{g} 10 \mathrm{MJ}^{-1}\right)$ & $23.7 \pm 6.3$ & $23.0 \pm 5.9$ \\
Fruit and vegetables $\left(\mathrm{g} 10 \mathrm{MJ}^{-1}\right)$ & $483 \pm 242$ & $486 \pm 244$ \\
Fish $\left({\left.\mathrm{g} 10 \mathrm{MJ}^{-1}\right)}^{159 \pm 141}\right.$ & $164 \pm 129$ \\
\hline
\end{tabular}

$\mathrm{SD}$ - standard deviation; $\mathrm{E} \%$ - percentage of energy.

${ }^{*} P<0.001$ compared with under-reporters (Mann-Whitney test).

When entered one-by-one in the multiple linear regression model described above, the percentage of energy from protein $(P=0.03)$ and the percentage of energy from added sugar $(P<0.001)$ remained statistically significantly associated with the degree of underreporting.

A tendency was found that under-reporters lost more weight during the registration period than acceptable reporters; $0.4 \pm 0.8$ versus $0.1 \pm 0.8 \mathrm{~kg}(P=0.06)$ for under-reporters and acceptable reporters, respectively.

Mean $\mathrm{EE}_{\mathrm{rep}}$ as a percentage of $\mathrm{EE}_{\text {mea }}$ for various subject characteristics are given in Table 5. Subjects who reported being very physically active at work or in leisure time reported a higher EE compared with measured EE than less physically active subjects $(P<0.05)$. Likewise, subjects who regarded themselves as fit or very fit seemed to report a higher EE compared with measured EE than subjects who did not regard themselves as fit $(P<0.05)$. Misreporting of EE was not related to sex, age, smoking status, education, BMI or view of their own health.

Under-reporting of EI was weakly correlated with under-reporting of $\mathrm{EE}(r=0.23, P=0.007)$, meaning that some of the subjects who under-report dietary intake also over-report EE (results not shown).

The time spent at various activity levels (very light, light, moderate and vigorous) and at various activity domains (transport, occupational, household, leisure, etc.) reported by acceptable reporters was compared with that reported by possible under-reporters and possible over-reporters, respectively. Possible under-reporters $(n=33)$ recorded more time as very light physical activity $(P<0.001)$, less time as light $(P=0.002)$ and less time as moderate physical activity $(P=0.01)$ than acceptable reporters (Fig. 1). Conversely, possible over-reporters ( $n=14$ by this definition) reported less time as very light physical activity $(P=0.007)$, more time as moderate $(P=0.01)$ and more time as vigorous physical activity $(P=0.02)$ than acceptable reporters. No significant differences were found between possible over-reporters and acceptable reporters with regard to time spent at the various activity domains. Likewise, no significant differences were found between time spent at various activity
Table 5 Reported energy intake as a percentage of measured energy expenditure and various subject characteristics

\begin{tabular}{|c|c|}
\hline & $\begin{array}{c}\mathrm{EE}_{\text {rep }} \text { as a percentage of } \\
\left.\mathrm{EE}_{\text {mea }} \text { (mean } \pm \mathrm{SD}\right)\end{array}$ \\
\hline \multicolumn{2}{|l|}{ Gender } \\
\hline $\operatorname{Men}(n=69)$ & $95.8 \pm 11.5$ \\
\hline Women $(n=69)$ & $97.3 \pm 8.4$ \\
\hline \multicolumn{2}{|l|}{ Age (years) } \\
\hline $20-29(n=33)$ & $99.1 \pm 10.4$ \\
\hline $30-39(n=36)$ & $93.8 \pm 8.7$ \\
\hline $40-49(n=34)$ & $96.1 \pm 10.4$ \\
\hline $50-59(n=35)$ & $97.4 \pm 10.5$ \\
\hline \multicolumn{2}{|l|}{ Smoking } \\
\hline Smokers $(n=18)$ & $95.0 \pm 10.8$ \\
\hline Occasional smokers $(n=6)$ & $98.3 \pm 10.4$ \\
\hline Non-smokers $(n=114)$ & $96.7 \pm 10.1$ \\
\hline \multicolumn{2}{|l|}{ Education } \\
\hline Student $(n=19)$ & $98.6 \pm 10.6$ \\
\hline None or $<12$ years $(n=44)$ & $97.2 \pm 11.5$ \\
\hline $13-14$ years $(n=17)$ & $101.3 \pm 9.1$ \\
\hline $15-16$ years $(n=27)$ & $96.0 \pm 9.3$ \\
\hline$\geq 17$ years $(n=31)$ & $92.2 \pm 7.4$ \\
\hline \multicolumn{2}{|l|}{$\mathrm{BMI}\left(\mathrm{kg} \mathrm{m}^{-2}\right)$} \\
\hline$<18.5(n=1)$ & $107.9 \pm 0$ \\
\hline $18.5-24.9(n=65)$ & $98.0 \pm 8.6$ \\
\hline $25-29.9(n=59)$ & $94.4 \pm 13.7$ \\
\hline$\geq 30(n=13)$ & $98.2 \pm 10.1$ \\
\hline \multicolumn{2}{|l|}{ How fit are you? } \\
\hline Very fit or fit $(n=50)$ & $99.4 \pm 9.2^{\mathrm{a}}$ \\
\hline OK $(n=64)$ & $94.8 \pm 10.7^{b}$ \\
\hline Not fit $(n=24)$ & $95.4 \pm 9.4^{*}$ \\
\hline \multicolumn{2}{|l|}{ Physical activity at work } \\
\hline Sedentary $(n=77)$ & $93.6 \pm 9.2^{\mathrm{a}}$ \\
\hline Stand/walk $(n=40)$ & $98.8 \pm 9.0$ \\
\hline Stand/walk and carry things $(n=15)$ & $101.6 \pm 9.8^{b}$ \\
\hline Heavy or fast work $(n=3)$ & $115.3 \pm 9.7^{* \star \star b}$ \\
\hline \multicolumn{2}{|l|}{ Physical activity in leisure time } \\
\hline None $(n=11)$ & $96.9 \pm 10.8$ \\
\hline Light $2-4$ h week $^{-1}(n=52)$ & $96.1 \pm 9.5$ \\
\hline Light $>4 \mathrm{~h}$ week ${ }^{-1}(n=61)$ & $95.2 \pm 9.3^{\mathrm{a}}$ \\
\hline More vigorous $>4 \mathrm{~h} /$ week $(n=14)$ & $103.8 \pm 13.0^{* \mathrm{~b}}$ \\
\hline \multicolumn{2}{|l|}{ Believe they are in good health } \\
\hline Excellent $(n=35)$ & $97.9 \pm 9.4$ \\
\hline Very good $(n=55)$ & $94.3 \pm 10.0$ \\
\hline Good $(n=41)$ & $98.2 \pm 10.2$ \\
\hline Not so good $(n=7)$ & $98.3 \pm 13.0$ \\
\hline
\end{tabular}

$E_{\text {rep }}$ - reported energy expenditure; $E_{\text {mea }}$ - measured energy expenditure; $\mathrm{SD}$ - standard deviation; BMI - body mass index.

${ }^{\star} P<0.05 ;{ }^{* \star} P<0.01 ;{ }^{* \star \star} P \leq 0.001$ (one-way analysis of variance).

${ }^{a b}$ Different letters indicate significant difference, $P<0.05$, by Tukey post hoc test. 


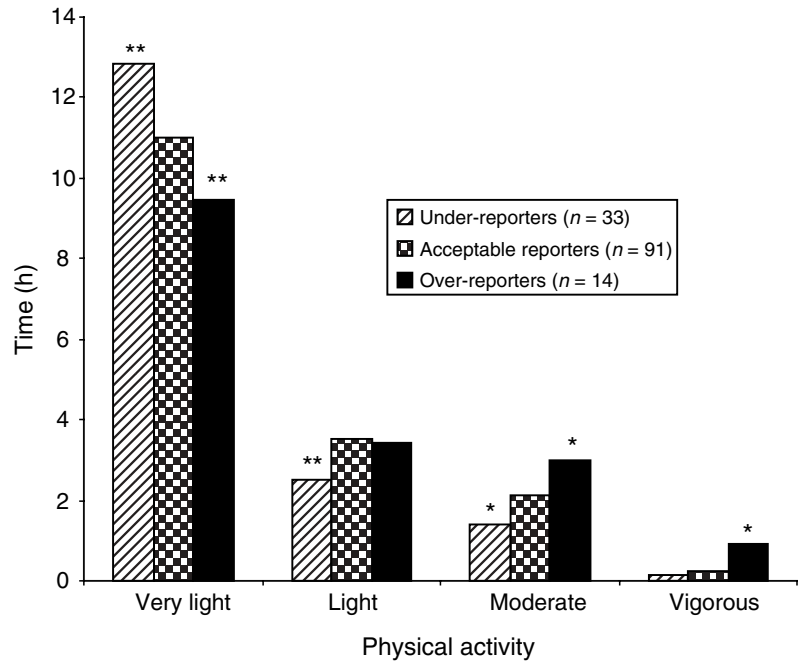

Fig. 1 Intensity of very light, light, moderate and vigorous physical activity in under-reporters of energy expenditure (EE), acceptable reporters of EE and over-reporters of EE $(n=138)$. ${ }^{*} P<0.03$, ${ }^{* \star} P<0.01$ compared with acceptable reporters

domains between possible under-reporters and acceptable reporters except for time spent at home (significantly lower in under-reporters $(P=0.018))$.

\section{Discussion}

In this study, we have tried to characterise misreporters of EI and EE. Most misreporters found were under-reporters of EI. We found that non-smokers, subjects with BMI $>30$ $\mathrm{kg} \mathrm{m}^{-2}$ and subjects who ate healthily to avoid being overweight under-reported EI mostly. Subjects who classified themselves as being fit reported a higher EE than subjects who regarded themselves as unfit. Furthermore, subjects who reported $<90 \%$ of $\mathrm{EE}_{\text {mea }}$ recorded more time as very light physical activity than acceptable reporters, whereas subjects who reported $>110 \%$ of $\mathrm{EE}_{\text {mea }}$ reported more time as moderate and vigorous physical activity than acceptable reporters.

We found very few over-reporters of EI. Thus, our study confirms a number of studies ${ }^{10}$ that showed that underreporting is the main problem in studies where dietary records are used.

The characteristics of subjects who under-report EI are not consistent among studies. An inverse relationship between BMI and under-reporting of EI has been found in most studies, as in the present study ${ }^{3,4,10,27,28}$. However, a relationship between age, sex, education and smoking and EI is not consistently found among studies.

A tendency for an individual to restrict food intake in order to lose weight or to prevent weight gain (restraint eaters) has been found to be related to a higher degree of under-reporting of EI, especially in women ${ }^{5}$. Likewise, an important factor in predicting under-reporting of EI is dissatisfaction with body image ${ }^{6}$. In agreement with this, we found that subjects who eat healthily to avoid being overweight under-reported EI to a higher degree than subjects who did not express any worries about their body weight.

A relevant question is: do the under-reporters undereat in the recording period or do they under-report food intake? The subjects who under-reported EI in the present study tended to lose more weight than subjects who did not under-report. Likewise, Goris and Westerterp ${ }^{29}$ found in highly motivated lean women that they lost weight during 1 week of dietary recording. Thus, part of the under-reporting in our study may be caused by actual undereating.

We found that the percentage energy from added sugar was lower and the percentage energy from protein was higher among under-reporters. A lower intake of sugar is a common finding ${ }^{10,11}$. In contrast to others, we did not find a lower percentage of energy from fat in under-reporters compared with acceptable reporters ${ }^{11,12,28,30,31}$.

The definition of misreporters influences the number of misreporters and probably the conclusion about the characteristics of the misreporters. For the characteristics given as categorical parameters, we chose to report EI as a percentage of $\mathrm{EE}_{\text {mea. }}$. By doing so, we did not have to define under-reporting. However, when exploring noncategorical data, we had to compare misreporters and acceptable reporters. In these cases, under-reporters of EI were defined as subjects below the 95\% CL of agreement between EI and EE. If we use the Goldberg cut-off ${ }^{13}, 8 \%$ of the subjects could be classified as under-reporters. This number is low compared with the Danish nationwide dietary study 2000/2001 where 24\% under-reported according to the Goldberg cut-off ${ }^{8}$. The same dietary diary was used in that study as in the present study.

The reason for the low number of under-reporters in the present study could be explained by the highly motivated volunteers. Many subjects participated because of an interest in health issues. Although the number of overweight subjects is relatively high and efforts were made to recruit subjects with various educational background, the study subjects are not representative of the Danish adult population; more subjects with a high educational level and fewer without any education participated in our study. Likewise, a small number of the subjects smoked.

One of the strengths of the present study is that we used an objective method as the reference method to measure EE. The ActiReg ${ }^{\circledR}$ system has been validated against both the doubly labelled water (DLW) method and indirect calorimetry, demonstrating no significant mean difference between EE measured with ActiReg ${ }^{\circledR}$ and EE measured with DLW or indirect calorimetry ${ }^{24}$. However, there are some limitations with the method, as ActiReg ${ }^{\circledR}$, like other objective instruments used to measure habitual physical activity and EE among free-living people, shows considerable variation at the individual level. In addition, certain types of activity such as arm work, carrying loads 
and water activities is not well accounted for due to the way Actireg ${ }^{\circledR}$ is designed. Actireg ${ }^{\circledR}$ measures body position and movements (trunk and right leg) and converts this into a PAL value. To calculate $\mathrm{EE}_{\text {mea }}$, an estimated value of individual BMR was used.

In contrast to our study, it is more common to have more over-reporters than under-reporters of $\mathrm{EE}^{15,16,31}$. This difference could be due to the use of different objective instruments to measure physical activity. As in this study, in another study which used ActiReg ${ }^{\circledR}$ to validate a PAQ, a higher EE was found with ActiReg ${ }^{\circledR}$ than with the questionnaire ${ }^{32}$

We found very few misreporters of EE, indicating good agreement between the PAQ and ActiReg ${ }^{\circledR}$. Subjects who claimed to be highly physically active at work or in leisure time reported a higher EE than measured by ActiReg ${ }^{\circledR}$. ActiReg $^{\circledR}$ does not measure vigorous physical activity well ${ }^{24}$, thus it is possible that the PAQ measures vigorous physical activity better than ActiReg ${ }^{\circledR}$. Experiments with ActiReg $^{\circledR}$ and DLW have shown that in individuals with PAL $>2.0$, measurement of heart rate should be included to improve the calculation of $\mathrm{EE}^{24}$. However, only a few people in the Danish population have a PAL $>2.0$ as demonstrated in the present study among highly motivated subjects, where only seven subjects had a PAL $>2.0$ according to ActiReg ${ }^{\circledR}$.

It is important to know whether the same individuals misreport both EI and EE because in many studies physical activity questionnaires are used to validate EI. Thus, if both $\mathrm{EI}$ and $\mathrm{EE}$ are under-reported, the subject might incorrectly be regarded as an acceptable reporter. In contrast, if EI is acceptably reported and EE is over-reported, a subject could erroneously be classified as an under-reporter. In the present study, only four (2.9\%) subjects misreported both EE and EI.

One could speculate whether the same mechanisms apply when recording physical activity as when recording dietary intake. In general, it is likely that subjects wish to put themselves in a positive light regarding health behaviour. In line with this, we found that subjects who regarded themselves as fit reported more EE compared with measured EE than subjects who did not regard themselves as fit. However, in our study, under-reporters of EI and misreporters of EE did not share the same characteristics and only a few of the misreporters of EE also misreported EI. A reason could be that all questions in the PAQ should be answered, in contrast to the dietary record where things can simply be left out; thus it may be easier deliberately to under-report dietary intake than to misreport EE.

We chose to define misreporters of EE in the same way as misreporters of EI as subjects outside the 95\% CLs of agreement between $\mathrm{EE}_{\mathrm{rep}} / \mathrm{EE}_{\text {mea }}$, which results in a small number of under-reporters. Thus, to be able to compare acceptable reporters and misreporters of EE with regard to their reported level of physical activity and time spent on various activity domains and the actual measured values, we defined acceptable reporters of EE as reporters within $90-110 \%$ of measured EE. A difference in time reported in various activity levels was found; under-reporters reported more time as very light, light and moderate physical activity than acceptable reporters, whereas over-reporters reported less time as very light physical activity and more time as moderate or vigorous physical activity.

In a study by Rzewnicki et al. ${ }^{16}$ using the IPAQ, $>40 \%$ over-reported vigorous and moderate physical activity. Over-reporting of vigorous physical activity has also been found in a study in 115 men and women who spent 2 days in a whole-room indirect calorimeter ${ }^{33}$. Light physical activity was reported accurately.

In conclusion, under-reporting of EI is a problem that should always be taken into consideration in dietary surveys, otherwise it may seriously bias the conclusions regarding dietary intake in various population groups and the relationship between dietary intake and disease. Furthermore, it is important to be aware that not all food items or nutrients are under-reported to the same degree. We found that mainly sugar was under-reported. We also found that subjects having a high BMI, non-smokers and subjects who ate healthily to avoid being overweight mostly under-reported EI. Misreporting of EE was found to be less common than misreporting of EI. The physical activity level more than the time spent on the various activity domains seems to be misreported.

\section{References}

1 Braam LAJLM, Ocké MC, Bueno-de-Mesquita B, Seidell JC. Determinants of obesity-related underreporting of energy intake. American Journal of Epidemiology 1998; 147: 1081-6.

2 Samaras K, Kelly PJ, Campbell LV. Dietary underreporting is prevalent in middleaged British women and is not related to adiposity (percentage body fat). International Journal of Obesity 1999; 23: 881-8.

3 Johansson G, Wikman A, Åhrén A-M, Hallmans G, Johansson I. Underreporting of energy intake in repeated 24-hour recalls related to gender, age, weight status, day of interview, educational level, reported food intake, smoking habits and area of living. Public Health Nutrition 2001; 4: 919-27.

4 Samuel-Hodge CD, Johnston LF, Fernandez LM, Keyserling TC, Henríquez-Roldán CF. A comparison of selfreported energy intake with total energy expenditure estimated by accelerometer and basal metabolic rate in African-American women with type 2 diabetes. Diabetes Care 2004; 27: 663-9.

5 Asbeck I, Mast M, Bierwag A, Westenhöfer J, Acheson KJ, Müller MJ. Severe underreporting of energy intake in normal weight subjects: use of an appropriate standard and relation to restrained eating. Public Health Nutrition 2000; 5: 683-90.

6 Novotny JA, Rumpler WV, Riddick H, Herbert JR, Rhodes D, Judd JT, et al. Personality characteristics as predictors of underreporting of energy intake on 24-hour dietary recall interviews. Journal of American Dietetic Association 2003; 103: $1146-51$.

7 Mendez MA, Wynter S, Wilks R, Forrester T. Under- and overreporting of energy is related to obesity, lifestyle factors 
and food group intakes in Jamaican adults. Public Health Nutrition 2004; 7: 9-19.

8 Fagt S, Matthiessen J, Biltoft-Jensen A, Groth MV, Christensen T, Hinsch H-J, et al. Udviklingen i Danskernes Kost 1985-2001 [Trends in the Danish Diet from 1995 to 2000/01]. Søborg: Danmarks Fødevare- og Veterinærforskning, 2004.

9 Briefel RR, Sempos CT, McDowell MA, Chien S, Alaimo K. Dietary methods research in the third National Health and Nutrition Examination Survey: underreporting of energy intake. American Journal of Clinical Nutrition 1997; 64(Suppl.): S1230-9.

10 Livingstone MB, Black AE. Markers of the validity of reported energy intake. Journal of Nutrition 2003; 133: S895-920

11 Lafay L, Mennen L, Basdevant A, Charles MA, Borys JM, Eschwége $\mathrm{E}$, et al. Does energy intake underreporting involve all kinds of food or only specific food items? Results from the Fleurbaix Laventie Ville Sante (FLVS) study. International Journal of Obesity 2000; 24: 1500-6.

12 Johansson L, Solvoll K, Bjørneboe G-EA, Drevon CA. Underand overreporting of energy intake related to weight status and lifestyle in a nationwide sample. American Journal of Clinical Nutrition 1998; 68: 266-74.

13 Goldberg GR, Black AE, Jebb SA, Cole TJ, Murgatroyd PR, Coward WA, et al. Critical evaluation of energy intake data using fundamental principles of energy physiology: 1. Derivation of cut-off limits to identify under-recording. European Journal of Clinical Nutrition 1991; 45: 569-81.

14 Black AE. The sensitivity and specificity of the Goldberg cut-off for EI:BMR for identifying diet reports of poor validity. European Journal of Clinical Nutrition 2000; 54: 395-404.

15 Sallis JF, Saelens BE. Assessment of physical activity by selfreport: status, limitations, and future directions. Research Quarterly for Exercise and Sports 2000; 71: 1-14.

16 Rzewnicki R, Auweele YV, De Bourdeaudhuij I. Addressing overreporting on the International Physical Activity Questionnaire (IPAQ) telephone survey with a population sample. Public Health Nutrition 2003; 6: 299-305.

17 Sallis JF, Buono MJ, Roby JJ, Micale FG, Nelson JA. Seven-day recall and other physical activity self-reports in children and adolescents. Medicine and Science in Sports and Exercise 1993; 25: 99-108.

18 Hayden HA, Sallis JF, Armstrong C, Whalen K, Sarkin J. Evaluation of the phone version of the seven day physical activity recall. Medicine and Science in Sports and Exercise 1998; 30: S14.

19 Lyhne N, Christensen T, Groth MV, Fagt S, Biltoft-Jensen A, Hartkopp H, et al. Danskernes Kostvaner 2000-2002. Hovedresultater [Dietary Habits in Denmark 2000-2002. Main Results]. Søborg: Danmarks Fødevareforskning, 2005.
20 Danish Food Composition Databank version 5 [online], October 2002. Available at www.foodcomp.dk

21 Schofield WN, Schofield C, James WPT. Basal metabolic rate: review and prediction. Humun Nutrition Clinical Nutrition 1985; 39: 1-96.

22 Craig CL, Marshall AL, Sjöström M, Bauman AE, Booth ML, Ainsworts BE, et al. International physical activity questionnaire: 12-country reliability and validity. Medicine and Science in Sports and Exercise 2003; 35: 1381-95.

23 Ainsworth BE, Haskell WL, Whitt MC, Irwin MC, Swartz AM, Strath SJ, et al. Compendium of physical activities: an update of activity codes and MET intensities. Medicine and Science in Sports and Exercise 2000; 32(Suppl. 9): S498-S516.

24 Hustvedt B-E, Christophersen A, Johnsen LR, Tomten H, McNeill G, Haggarty P, et al. Description and validation of the ActiReg ${ }^{\circledR}$ : a novel instrument to measure physical activity and energy expenditure. British Journal of Nutrition 2004; 92: 1001-8.

25 Garby L, Garrow JS, Jørgensen B, Lammert O, Madsen K, Sørensen $\mathrm{P}$, et al. Relation between energy expenditure and body composition in man: specific energy expenditure in vivo of fat and fat-free tissue. European Journal of Clinical Nutrition 1988; 42: 301-5.

26 Heitmann BL. Prediction of body water and fat in adult Danes from measurement of electrical impedance. International Journal of Obesity 1990; 14: 789-802.

27 Tooze JA, Subar AF, Thompson FE, Troiano R, Schatzkin A, Kipnis V. Psychosocial predictors of energy underreporting in a large doubly labeled water study. American Journal of Clinical Nutrition 2004; 79: 795-804.

28 Mattisson I, Wirfält E, Aronsson CA, Wallström P, Sonestedt E, Gullberg B, et al. Misreporting of energy: prevalence, characteristics of misreporters and influence on observed risk estimates in the Malmö diet and cancer cohort. British Journal of Nutrition 2005; 94: 832-42.

29 Goris AHC, Westerterp KR. Underreporting of habitual food intake is explained by undereating in highly motivated lean women. Journal of Nutrition 1999; 129: 878-82.

30 Bingham SA, Cassidy A, Cole TJ, Welch A, Runswick SA, Black AE, et al. Validation of weighed records and other methods of dietary assessment using the $24 \mathrm{~h}$ urine nitrogen technique and other biological markers. British Journal of Nutrition 1995; 73: 531-50.

31 Rutishauser IHE. Is dietary underreporting macronutrient specific? European Journal of Clinical Nutrition 1997; 49: 219-20.

32 Solberg M, Anderssen SA. Utarbeidelse av Målemetoder for Måling av Fysisk aktivitet [Methods for Measuring Physical Activity]. Norway: NIH, 2002.

33 Buchowski MS, Townsend KM, Chen KY, Acra SA, Sun M. Energy expenditure determined by self-reported physical activity is related to body fatness. Obesity Research 1999; 7: $23-33$. 